\title{
Determination of the Thermal Neutron Fluence in Recoil Tritiation by the ${ }^{6} \mathrm{Li}(\mathrm{n}, \boldsymbol{a})^{3} \mathrm{H}$ Reaction
}

\author{
Norio Nogawa, Kunio OoHashi*, Hiromitu MatuOKA**, \\ Kiyoshi HoIZUMI**, Terutomi MOKI**, Takashi MORIYA**, \\ and Naotake MORIKAWA \\ Radioisotope Centre, The University of Tokyo \\ Yayoi, Bunkyo-ku, Tokyo 113 \\ *Department of Chemistry, College of Arts and Sciences, Chiba University \\ Yayoi, Chiba-shi 260 \\ **Radioisotope Center, Japan Atomic Energy Research Institute \\ Tokai-mura, Naka-gun, Ibaraki Pref. 319-11 \\ Received December 26, 1986
}

\begin{abstract}
Lithium benzoate was irradiated at various thermal neutron fluence in reactors. A plot of the specific activity of benzoic acid derived from irradiated lithium benzoate vs. the thermal neutron fluence measured with ${ }^{59} \mathrm{Co}$ activation detectors gave a linear relationship on a logarithmic graph paper in the range of thermal neutron fluence from $1.3 \times 10^{14}$ to $2.2 \times 10^{17} \mathrm{n}^{\mathbf{1}} \mathrm{cm}^{-2}$. This finding indicates that lithium benzoate is available as an activation detector for recoil tritiation by the ${ }^{6} \mathrm{Li}(n, \alpha)^{3} \mathrm{H}$ reaction.
\end{abstract}

Key Words: thermal neutron fluence, lithium-6, tritium, neutron alpha reaction, lithium benzoate, recoil tritiation

\section{Introduction}

We have studied tritiation of organic compounds with recoil tritium atoms in such systems as lithium salts, lithium alkoxides, or mixtures with inorganic lithium salts ${ }^{1}$. In the course of the studies, the accurate values were required for thermal neutron fluence irradiated to the sample to compare the radiochemical yields of separately irradiated samples.

In case of the tritiation by the ${ }^{6} \operatorname{Li}(\mathrm{n}, \alpha)^{3} \mathrm{H}$ reaction, lithium benzoate has been conveniently used to measure the thermal neutron fluence in a similar manner as ${ }^{59} \mathrm{Co}$ and ${ }^{197} \mathrm{Au}^{2)-4)}$. In addition to the linear relationship between the specific activity of benzoic acid obtained from irradiated lithium benzoate and the value of thermal neutron fluence on a logarithmic graph paper, some desirable properties as the activation detector were observed for lithium benzoate. The incorporation of tritium into the aromatic ring occurs in a high efficiency, the intramolecular tritium distribution in the aromatic ring is reproducible within experimental error, and a little radiolysis occurs in the fluence range for usual use $\left(\leq 10^{-16}\right)$. Thus, lithium benzoate containing lithium in molecular dispersion seems to be a suitable material to estimate the thermal neutron fluence irradiated for a sample in the recoil tritiation by the ${ }^{6} \mathrm{Li}(\mathrm{n}, \alpha)^{3} \mathrm{H}$ reaction.

\section{Experimental}

\section{$2 \cdot 1 \quad$ Materials}

Co-Al alloy wire of 0.03 inch $(0.76 \mathrm{~mm})$ diameter was supplied from Reactor Experiments Inc. The stated content of ${ }^{59} \mathrm{Co}$ in the wire is $0.475 \%$. Cobalt- 59 foil $(100 \%$ isotopically pure) was obtained from Johnson Matthay Co. Ltd. Cadmium pipe $(2.3 \mathrm{~mm}$ o.d. and $0.5 \mathrm{~mm}$ thick) was purchased from Reactor Experiments Inc. Lithium carbonate was obtained from Nihon Rikagaku Yakuhin Co. Ltd. A mass spectrometric analysis shows that the isotopic abundance of ${ }^{6} \mathrm{Li}$ is 7.42 atom $\%$. Lithium benzoate was prepared from lithium carbonate and purified benzoic acid. Anal. Calcd for $\mathrm{C}_{7} \mathrm{H}_{6} \mathrm{O}_{2}: C, 68.84 ; \mathrm{H}, 4.95$. Found: C, 68.98; H, 5.00. Calcd for $\mathrm{C}_{7} \mathrm{H}_{5} \mathrm{O}_{2} \mathrm{Li}: \mathrm{C}$, $65.65 ; \mathrm{H}, 3.94$. Found: $\mathrm{C}, 65.64 ; \mathrm{H}, 4.00$. 
$n-\left[1,2(\mathrm{n})-{ }^{3} \mathrm{H}\right]-H e x a d e c a n e$ was obtained from Amersham, as a radioactivity standard.

\subsection{Preparation and irradiation of samples}

Quartz ampoules of $9 \mathrm{~mm}$ o.d. and $100 \mathrm{~mm}$ length were used for irradiation. In each quartz ampoule was placed about $0.5 \mathrm{~g}$ of lithium benzoate and the ampoule was sealed under an air pressure of ca. $20 \mathrm{mPa}\left(10^{-4}\right.$ Torr $)$. Two ${ }^{50} \mathrm{Co}$ activation detectors and the other one covered with cadmium pipe were attached to the ampoule at such positions as shown in Fig. 1. The samples were irradiated in the T-pipe of the JRR-4 reactor at Japan Atomic Energy Research Institute (nominal thermal neutron flux density: $8 \times 10^{13} \mathrm{n} \mathrm{cm}^{-2} \mathrm{~s}^{-1}$, nominal cadmium ratio: 7) or in the rotary specimen racks of TRIGA Mark II reactor at Institute for Atomic Energy of Rikkyo University, Japan (nominal thermal neutron flux density: $5 \times$ $10^{11} \mathrm{n} \mathrm{cm}^{-2} \mathrm{~s}^{-1}$, nominal cadmium ratio: 3.5 ). The Co-Al alloy wire was used for irradiation in the JRR-4 reactor and the ${ }^{50} \mathrm{Co}$ foil in the TRIGA Mark II reactor.

\subsection{Separation and purification of benzoic acid}

The ampoule was opened and the lithium benzoate was dissolved in water. The aqueous solution was submitted to the reverse isotope dilution analysis in order to obtain the chemical yield of tritium labeled benzoic acid. Then,

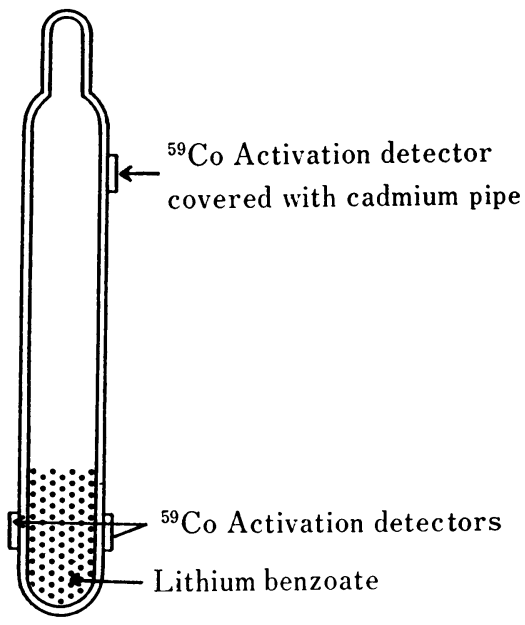

Fig. 1 Sample unit for neutron irradiation equipped with ${ }^{59} \mathrm{Co}$ activation detectors. the solution was extracted with ether to remove organic impurities produced during the irradiation. To the solution was added an enough amount of dilute sulfuric acid and the precipitate of benzoic acid was recovered with ether. After removal of ether, the benzoic acid was treated with activated charcoal, sublimed, and purified by repeated crystallization from water until it showed a constant specific activity.

\subsection{Measurement}

$\gamma$-Rays emitted from ${ }^{80} \mathrm{Co}$ in the irradiated ${ }^{\infty} \mathrm{Co}$ activation detector were counted with a $\mathrm{Ge}(\mathrm{Li})$ semiconductor detector (ORTEC Corp.), and the data were put on a cassette tape. The thermal neutron fluence irradiated for the sample was computed from the counting data by the use of the program of $B O B 75^{\circ}$. The measured cadmium ratios are $12 \pm 1$ for irradiation in the TRIGA Mark II reactor and $15 \pm 5$ or $26 \pm 1$ for that in the JRR-4 reactor. The standard deviation of the computed thermal neutron fluence is $5.6 \%$.

Activity of the tritiated benzoic acid was measured with Packard Tri-Carb liquid scintillation counters Model 3380 or 3255 . The determination of specific activity from counting rates have been described elsewhere ${ }^{\text {f). }}$. The counting efficiency of a non-quenching sample was determined with $n-\left[1,2(\mathrm{n})-{ }^{3} \mathrm{H}\right]$-hexadecane as a radioactivity standard. Each sample was counted for a period sufficient to reduce the standard deviation to $0.1 \%$ at the 1-sigma confidence level.

2.5 Application of lithium benzoate activation detector

A mixture of benzoic acid and lithium carbonate in a 2:1 mole ratio was prepared in a dry nitrogen atmosphere just prior to charging it. About $0.5 \mathrm{~g}$ of the mixture was placed in a quartz ampoule of $12 \mathrm{~mm}$ o.d. and $100 \mathrm{~mm}$ length and the ampoule was sealed under a nitrogen pressure of $\mathrm{ca} .20 \mathrm{mPa}\left(10^{-4}\right.$ Torr). To this sample was attached two lithium benzoate activation detectors as shown in Fig. 2 . These were prepared by sealing about $0.2 \mathrm{~g}$ of lithium benzoate in each quartz tube of $3.7 \mathrm{~mm}$ o.d. and $100 \mathrm{~mm}$ length under an air pressure 
of ca. $20 \mathrm{mPa}\left(10^{-1}\right.$ Torr $)$. Irradiation was carried out in the TRIGA Mark II reactor. After irradiation, benzoic acid was recovered, purified, and its activity was counted as described above. A control experiment was also carried out with a sample containing lithium benzoate.

\section{Results and Discussion}

3.1 Lithium benzoate activation detector

Table 1 shows the data on irradiation of the lithium benzoate samples equipped with the ${ }^{59} \mathrm{Co}$ activation detectors. The plot of the specific activity of benzoic acid vs. the thermal neutron fluence are given in Fig. 3. This plot based on the activation detector data is approximately linear, while the plot of the specific activity of benzoic acid vs. the irradiation time of ten deviates from the straight line. This findings shows that lithium benzoate is useful as an activation detector for the nuclear transformation, ${ }^{6} \mathrm{Li}(\mathrm{n}, \alpha)^{3} \mathrm{H}$. The plot in Fig. 3 was formulated by the Eq. (1) from calculation by the least squares method:

$$
N=2.27 \times 10^{12} S^{1.026}
$$

where $N$ is the thermal neutron fluence $\left(\mathrm{ncm}^{-2}\right)$ and $S$ the specific activity $\left(\mathrm{Bq}^{-1}\right)$ of benzoic acid derived from the irradiated lithium benzoate. Thus, the thermal neutron fluence $(N)$ irradiated

Table 1 Values of thermal neutron fluence determined with ${ }^{59} \mathrm{Co}$ activation detectors and specific activity of tritiated benzoic acid from irradiated lithium benzoate

\begin{tabular}{|c|c|c|c|c|c|}
\hline \multirow{2}{*}{$\begin{array}{l}\text { Reactor } \\
\text { [date of irradiation] } \\
\text { (cadmium ratio) }\end{array}$} & \multirow{2}{*}{$\begin{array}{l}\text { Irradiation time } \\
\qquad(\min )\end{array}$} & \multirow{2}{*}{$\begin{array}{l}\text { thermal } \\
\text { neutron } \\
\text { fluence } \\
\left(\mathrm{n} \mathrm{cm}^{-2}\right)\end{array}$} & \multicolumn{3}{|c|}{ Tritiated benzoic acid } \\
\hline & & & $\begin{array}{l}\text { Specific activity } \\
\left(\times 10^{3} \mathrm{~Bq} \mathrm{mg}^{-1}\right)\end{array}$ & $\begin{array}{c}\text { Chemical yield } \\
(\%)\end{array}$ & $\begin{array}{c}\text { Radiochemical yield } \\
(\%)\end{array}$ \\
\hline \multirow{6}{*}{$\begin{array}{l}\text { TRIGA Mark II } \\
\text { [Mar., 1979] } \\
(12 \pm 1)\end{array}$} & & $\left(\times 10^{14}\right)$ & & & \\
\hline & 5 & 1.33 & 0.0531 & & \\
\hline & 30 & 7.97 & 0.297 & & \\
\hline & 60 & 16.1 & 0.583 & & \\
\hline & 205 & 53.9 & 1.85 & & \\
\hline & 240 & 61.2 & 2.12 & & \\
\hline \multirow{8}{*}{$\begin{array}{c}\text { JRR-4 } \\
{[\text { May, 1978] }} \\
(15 \pm 5)\end{array}$} & & $\left(\times 10^{16}\right)$ & & & \\
\hline & 5 & 1.15 & 4.27 & 100 & 60 \\
\hline & 10 & 1. 78 & 6.44 & 100 & 58 \\
\hline & 10 & 1.95 & 7.07 & 100 & 58 \\
\hline & 15 & 3.53 & 12.7 & 96 & 55 \\
\hline & 20 & 3.70 & 13.2 & 96 & 55 \\
\hline & 20 & 4.20 & 14.5 & 97 & 54 \\
\hline & 25 & 4.37 & 15.2 & 96 & 53 \\
\hline \multirow{6}{*}{$\begin{array}{l}\text { JRR-4 } \\
\text { [Nov., 1978] } \\
\quad(15 \pm 5)\end{array}$} & & $\left(\times 10^{16}\right)$ & & & \\
\hline & 5 & 0.99 & 3.57 & 100 & 57 \\
\hline & 10 & 2.30 & 7.87 & 99 & 54 \\
\hline & 15 & 3.30 & 11.3 & 100 & 55 \\
\hline & 20 & 2.77 & 10.3 & 100 & 59 \\
\hline & 25 & 6.41 & 22.4 & 95 & 53 \\
\hline \multirow{5}{*}{$\begin{array}{c}\text { JRR-4 } \\
\text { [D€c., 1985] } \\
(26 \pm 1)\end{array}$} & & $\left(\times 10^{16}\right)$ & & & \\
\hline & 30 & 6.28 & 21.2 & 89 & 48 \\
\hline & 60 & 11.9 & 37.9 & 81 & 42 \\
\hline & 90 & 16.0 & 49.3 & 75 & 37 \\
\hline & 120 & 22.3 & 68.2 & 66 & 33 \\
\hline
\end{tabular}

\footnotetext{
* Average values calculated from the cobalt-60 activities of two activation detectors attached to one sample.
} 


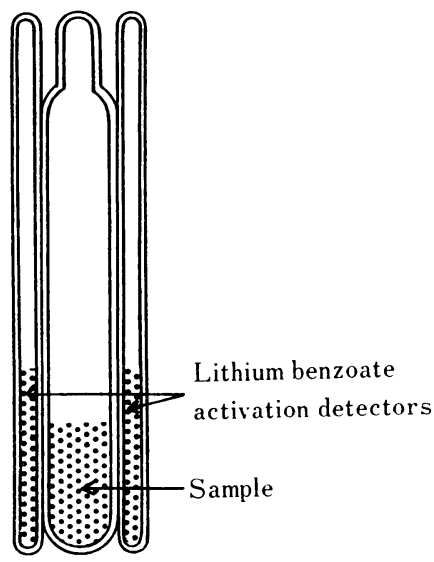

Fig. 2 Sample unit for neutron irradiation equipped with lithium benzoate activation detectors.

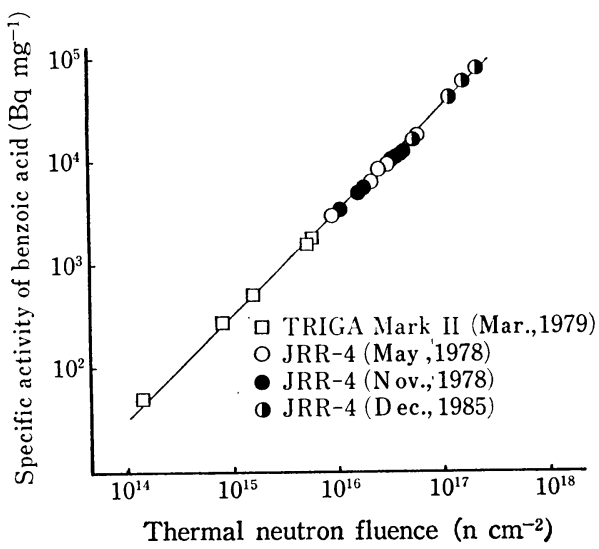

Fig. 3 Plot of specific activity of benzoic acid vs. values of thermal neutron fluence determined with ${ }^{59} \mathrm{Co}$ activation detectors.

for a sample can be calculated by Eq. (1) from the specific activity of benzoic acid derived from the lithium benzoate activation detectors attached to the ampoule containing irradiation sample. The deviation between the values of thermal neutron fluence calculated by Eq. (1) and those measured with ${ }^{59} \mathrm{Co}$ activation detectors is within $\pm 7.5 \%$.

Lithium benzoate is decomposed by recoil tritium atoms and alpha particles as well as background pile radiation during the irradiation. The chemical yields of benzoic acid show that the radiolysis of lithium benzoate is less than $34 \%\left(2.2 \times 10^{17} \mathrm{n} \mathrm{cm}^{-2}\right)$ under the present irradiation conditions. The radiochemical yields for benzoic acid extend from 33\% to $60 \%$ of the produced tritium and decrease with increasing thermal neutron fluence. This decrease seems mainly to depend upon increasing radiolysis of lithium benzoate (Table 1).

The lithium benzoate activation detector was developed on purpose to apply to hot atom reaction by ${ }^{6} \mathrm{Li}(\mathrm{n}, \alpha){ }^{3} \mathrm{H}$ reaction. Application of this detector to the nuclear reaction always involves comparison of radioactivities obtained from the same nuclear reaction. That is to say, in this case both a sample and a detector are allowed an exposure to neutrons in the same range of energy spectrum. As seen in Figs. 1 and 2, the detector in a quartz tube can be effective throughout the entire length of the sample, whereas with such generally used activation detectors as ${ }^{59} \mathrm{Co}$ only part of a bulky sample is covered. The present detector is helpful in laboratories which only $\beta$-emitters are used and accordingly such apparatus for $\gamma$-rays as a $\mathrm{Ge}(\mathrm{Li})$ semiconductor detector are

Table 2 Radiochemical yield of the tritiated benzoic acid in the lithium benzoate and $\mathrm{PhCOOH}-\mathrm{Li}_{2} \mathrm{CO}_{3}$ mixture systems

\begin{tabular}{|c|c|c|c|c|c|c|}
\hline \multirow{3}{*}{ Run No. } & \multirow{3}{*}{ Sample } & \multicolumn{2}{|c|}{$\mathrm{PhCOOLi}$ activation detector } & \multirow{2}{*}{$\begin{array}{l}\text { Specific activity } \\
\left(\times 10^{3} \mathrm{~Bq} \mathrm{mg}^{-1}\right) \\
\end{array}$} & \multirow{2}{*}{$\begin{array}{c}\text { Chemical yield } \\
(\%)\end{array}$} & \multirow{2}{*}{$\begin{array}{l}\text { Radiochemical yield } \\
(\%)\end{array}$} \\
\hline & & \multirow{2}{*}{$\begin{array}{l}\text { Specific activity } \\
\text { of } \mathrm{PhCOOH} \\
\left(\times 10^{3} \mathrm{~Bq} \mathrm{mg} \mathrm{m}^{-1}\right)\end{array}$} & \multirow{2}{*}{$\begin{array}{l}\text { Therm alneutron } \\
\text { fluence } \\
\left(\times 10^{15} \mathrm{n} \mathrm{cm}^{-2}\right)\end{array}$} & & & \\
\hline & & & & \multicolumn{3}{|c|}{ of benzoic acid from samples } \\
\hline 1 & PhCOOLi & 3.30 & 9.2 & 3.38 & 100 & 59 \\
\hline 2 & $\begin{array}{l}\mathrm{PhCOOH}^{*} \\
+ \\
\mathrm{Li}_{2} \mathrm{CO}_{3}\end{array}$ & 3.35 & 9.4 & 2.18 & 100 & 38 \\
\hline 3 & $\begin{array}{c}\mathrm{PhCOOH}^{*} \\
+ \\
\mathrm{Li}_{2} \mathrm{CO}_{3}\end{array}$ & 3.41 & 9.6 & 2.29 & 100 & 39 \\
\hline
\end{tabular}

* Mixtures of $2: 1$ mole ratio 
not available. The authors have recently heard that the content of ${ }^{6} \mathrm{Li}$ in commercial lithium carbonate may vary from reagent to reagent. Lithium carbonate of a known ${ }^{6} \mathrm{Li}$-content is desirable. However, if once the isotopic abundance of ${ }^{6} \mathrm{Li}$ in lithium carbonate is obtained by mass spectrometry, its lithium carbonate can be used as a standard sample to determine the content of ${ }^{6} \mathrm{Li}$ in other lithium-containing reagents by activation in nuclear reactors. An example of the application other than to the ${ }^{6} \mathrm{Li}(\mathrm{n}, \alpha){ }^{3} \mathrm{H}$ reaction so far is known in that to the ${ }^{3} \mathrm{He}(\mathrm{n}, \mathrm{p})^{3} \mathrm{H}$ reaction ${ }^{4}$.

\section{$3 \cdot 2$ Application}

The lithium benzoate activation detector was applied in order to compare the radiochemical yield in a homogeneous system containing lithium in a molecular dispersion with that in an inhomogeneous system regarding dispersion of lithium. The data are shown in Table 2 . The specific activity of benzoic acid obtained from the activation detector is the same as that from the lithium benzoate sample within experimental error. This indicates that the application is valid. In irradiation of the $\mathrm{PhCOOH}-\mathrm{Li}_{2} \mathrm{CO}_{3}$ mixtures, the radiochemical yield of benzoic acid is on the average $39 \%$ of the produced tritium in the case of a thermal neutron fluence of $9.6 \times 10^{15} \mathrm{n} \mathrm{cm}^{-2}$. The duplicates ageeed within experimental error. This yield is $66 \%$ of that for the lithium benzoate sample. In the experiments performed in a lower fluence region, the observed chemical yield of benzoic acid was found to be not only $100 \%$ for the homogeneous lithium benzoate but also $100 \%$ for the inhomogenous $\mathrm{PhCOOH}-\mathrm{Li}_{2} \mathrm{CO}_{3}$ mixture in contrast to the previous finding ${ }^{1)}$. Therefore, a less radiochemical yield in the latter system is attributed to a poor efficiency of incorporation of tritium into the aromatic ring.

\section{References}

1) Morikawa, N., Oohashi, K., Saito, T. and Simamura, O.: Chem. Commun., 899900 (1966)

2) Oohashi, K., Ohmura, M., Maruyama, H. et al.: 28th Radiochemistry Symposium of Japan, Kobe, p. 187 (1984)

3) Maruyama, H., Oohashi, K., Matuoka, H. et al.: 29th Radiochemistry Symposium of Japan, Funabashi, p. 40 (1985)

4) Nogawa, N., Oohashi, K., Matuoka, H. et al.: J. Radioanal. Nucl. Chem. Lett., 106, 47-54 (1986)

5) Baba, H., JAERI-M 7017 (1977)

6) Saito, T., Oohashi, K. and Morikawa, N.: Radioisotopes, 30, 596-598 (1981) 
要旨

\section{${ }^{6} \mathrm{Li}(\mathrm{n}, \boldsymbol{a}){ }^{3} \mathrm{H}$ 反応を利用した反跳トリチウム化における熱中性子フルエンスの測定}

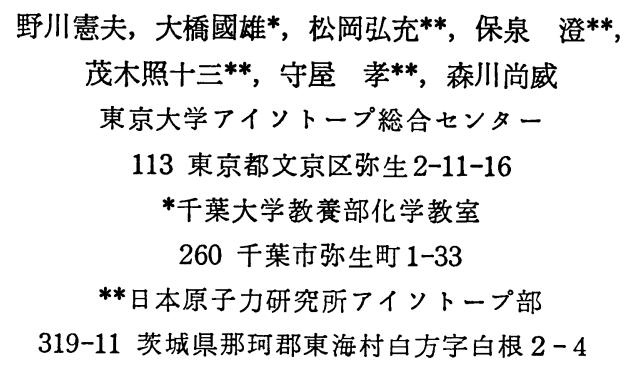

安息香酸リチウムを原子炉で種々の条件で熱中性子照射した。照射された安息香酸りチウムから 得られる $\left[{ }^{3} \mathrm{H}\right]$ 安息香酸の比放射能と, ${ }^{59} \mathrm{Co}$ 放射化検出器で測定された熱中性子フルエンスとの関 係を対数グラフ用紙に表すと, 熱中性子フルエンスが $1.3 \times 10^{14}-2.2 \times 10^{17} \mathrm{n} \mathrm{cm}^{-2}$ の範囲に打い て, 直線関係が成り立つ。このことは, 安息香酸りチウムが ${ }^{6} \mathrm{Li}(\mathrm{n}, \alpha)^{3} \mathrm{H}$ 反応による反跳卜リチウ ム化の放射化検出器として利用できることを示している。 